\begin{tabular}{lll}
\hline DE & DE GRUYTER \\
OPEN & ECONOMIC THEMES (2016) 54(3): 363-383 \\
& DOI 10.1515/ethemes-2016-0018 \\
\hline
\end{tabular}

\title{
THE INTERDEPENDENCE OF LEADER-MEMBER EXCHANGE RELATION AND THE LEADERSHIP STYLE: RESEARCH IN SERBIAN ORGANISATIONS
}

\author{
Vesna Stojanović Aleksić \\ University of Kragujevac, Faculty of Economics, Republic of Serbia \\ $\bowtie$ vesnasa@kg.ac.rs \\ Milena Stanisavljević \\ University of Kragujevac, Faculty of Technical Sciences, Republic of Serbia \\ $\triangle$ milena.stanisavljevic@ftn.kg.ac.rs
}

\author{
Aleksandra Bošković \\ University of Kragujevac, Faculty of Economics, Republic of Serbia \\ \aboskovic@kg.ac.rs
}

UDC

$005.96(497$.

11)

Original

scientific

paper

\begin{abstract}
The interdependence of leader behaviour, leadership styles and interpersonal relations with followers suggests a need to investigate various aspects of leadership from the perspective of a follower, which is the main subject of the paper. The study aims to determine the quality of leader-member exchange (LMX) in order to reach a conclusion on whether the perception of followers on the quality of LMX affects the leadership style and which style is the most commonly used. The empirical research was conducted in 2015 , in the Republic of Serbia, on a sample of 100 respondents, employees in 12 organisations, using the survey method. The results show there is the highest positive correlation between high quality LMX and participatory leadership style. In the opinion of the followers, achievement-oriented style is the most common, regardless of the fact that there are high quality LMX in the majority of companies in the sample. The importance of research is in highlighting the role of followers in the process of organisational leadership, as active and equal participants. Practical contribution is reflected in giving guidance for leaders for more active involvement of followers in the decision making process and adapting leadership style to specific traits of followers and the situational circumstances. Studies of this type are not often in the local organisational theory and practice.
\end{abstract}

Received: 13.01.2016. Accepted: 22.07.2016. leadership, leadership style, interpersonal relations, followers

JEL classification: D23, D22, M21 


\section{Introduction}

Leadership as a process in which the individual realises the impact on the group to achieve a common goal, is the subject of intense attention of the academic and professional community for decades. In most cases, attention is focused primarily on the leaders, with often losing sight of the fact that the leadership process consists of two basic dimensions: a leader and a follower. The leaders influence followers, and vice versa, which is why the leadership must be viewed as a two-way interactive process. It is a process in which leaders generate new ideas, articulating a common vision that corresponds with the values, motivations and perceptions of followers (House, 1995, according to Islam, ur Rehman, \& Ahmed, 2013, p. 81). Leadership involves the ability to influence followers, in order to achieve organisational tasks, using appropriate motivational techniques, based on the power and authority (Islam et al., 2013, p. 81), which indicates that followers interpret the actions of leaders in different ways, and it is the way in which the behaviour of a leader is perceived by followers that determines, reciprocally, their behaviour (Casimir \& Kerth Ng, 2010).

Earlier theories of leadership studies looked at the leadership as an activity that leaders take towards all his followers, uniformly, using the so-called average leadership style (Northouse, 2008). However, new theories bring into question this assumption, which is particularly related to the theory of exchange leader - follower, in literature known as LMX (Leader Member Exchange) model (Graen \& Uhl-Bien, 2005), according to which the leader establishes a specific relationship with each his followers individually. The LMX theory shows that a leader influences followers through the exchange that takes place through developed interpersonal relationships, which means that the leader does not behave the same towards all his followers, but he/she sets high quality relationships with some followers, while establishing significantly lower quality relationships with others.

Unlike previous theories and approaches to leadership that observe this process through the establishment of relations of the leaders and entire groups, two-track approach focuses on the relationship leader - an individual member of a group, i.e. a follower. Representatives of this theory (Graen \& Uhl-Bien, 2005; Northouse, 2008; Casimir \& Kerth Ng, 2010) believe that leadership is not a process that is manifested uniformly to all members of the organisation, but that leader forms a specific relationship with each member of the group individually, which implies that one cannot speak about the behaviour generally task-oriented or interpersonal-issues-oriented, which the most previous theories imply, but each interaction must be considered individually.

Depending on the quality of trade, the followers will behave in different ways, have different performance, be more or less satisfied with the job. In the 
context of these relationships the path - goal theory of leadership style can be observed. According to this theory the leader motivates followers by using different styles of leadership in different situations and depending on the specific characteristics of followers. As followers have equal importance in this interactive relationship, it is important to study how they perceive the behaviour of a leader or leadership styles, and how they assess the quality of exchange relations with their leaders. The behaviour of leaders, leadership styles and interpersonal relationships affect followers in multiple ways, and vice versa, which is why it is necessary to explore different aspects of leadership from the perspective of a follower, which is the main subject and the purpose of this paper.

The paper is structured in four parts. The first part refers to the review of the theoretical basis for conducting research, with the review of the basic postulates of the LMX theory and the path-goal theory. The second part explains the research methodology, defined aims, hypothesis and research methods. The third section presents the results of the empirical research. The last part contains a discussion of the results, conclusions, limitations and suggestions for future research.

\section{Leader-Member Exchange Theory}

In LMX theory, leadership is defined as a process in which interactions between leaders and followers are in the centre (Northouse, 2008, p. 103). Many theories of leadership assume that leaders behave the same with all employees. In reality, leaders most often behave differently towards individual followers and develop a completely different kind of relationship with them. The starting point of the LMX theory is that different types of relationship between the leader and his followers are developed within business units or organisational group (Dansereau, Graen, \& Haga, 1975, according to Gómez \& Rosen, 2001; Graen \& Scadura, 1987; Liden \& Graen, 1980), where the followers can be divided into two groups: internal and external group (Dienesch \& Liden, 1986, p. 621). High-quality exchange relations (characterized by trust, respect and loyalty) are developed with the followers of the inner group, while there are low-quality relations (characterized by mistrust, low esteem and lack of loyalty) between leader and the followers of external group. Effective leadership is achieved when leaders and followers develop mature relationships of partnership and achieve mutual benefits from such relationships (Graen Uhl \& Bein, 1995, p. 225). Followers realise benefits in the form of status, information, resources, awards, promotions and other benefits, while leaders in return expect the achievement of organisational goals, support and commitment to the organisation (Cookson, 2011). Leaders develop different expectations of different followers. Therefore, they expect more performance and higher quality 
of tasks with followers of the inner group with whom they have a high quality exchange relations (Jiang, Law, \& Sun, 2014). The quality of exchange between the leader and follower affects the individual, group and organisational performance (Gerstner \& Day, 1997; according to Mumma, 2010; Graen \& Uhl-Bein, 1995). Evaluation of the performance of employees and the level of delegation depends directly on the quality of trade between leaders and followers (Bauer \& Green, 1996, according to Gómez \& Rosen, 2001, p. 57).

Two-track approach to leadership, LMX model, as already mentioned, relies on the theory of leader-member exchange (Graen \& Uhl-Bien, 2005). The basic premise of this theory is based on the idea of reciprocal influence of leaders on followers, which can take two different forms. It is believed that most leaders established specific exchange relations with a small number of members of a group, with whom he has close relations, so they have the role of his aides and advisers, while the second part of the group members becomes relatively neglected, or leaders can establish worse relations with them, which is why they are often viewed as opponents of leaders. In the exchange with these members of the group a relatively low level of mutual influence is expressed and it is based largely on the legitimate sources of power and authority, and implemented within the formally defined rules and procedures. More complex exchange relations that are established with preferred members of the group imply that these members are receiving more attention, recognition and opportunities for advancement, but they are expected to provide greater involvement, commitment to the objectives and mission, and greater loyalty to the leader, in return.

Members of the internal group, according to this theory, are selected based on their skills, their motivation to take on greater responsibility and the extent to which leaders believe that employees can trusted (Liden \& Graen, 1980, p. 451). Followers who show a higher degree of efficiency, who are nice and have similar personality traits as a leader, will become members of internal groups (Lunenburg, 2010; Schyns, Kroon, \& Moors, 2008). These employees contribute to the business operations more than is expected of them according to the formal requirements of the job and they take responsibility for the performance of activities that are most critical to the success of the organisation. They have a special treatment by the leader, in the sense that they provide a greater amount of information, greater commitment, attention, support in career development, understanding and they enjoy greater trust and caring by leader (Jiang, et al., 2014; Lunenburg, 2010). They also have a greater responsibility, greater productivity and autonomy in decision-making. Followers of the inner group have more opportunities to speak openly, to share information and ideas with their supervisor, to use multiple channels of communication, compared to followers from outside groups (Vukonjanski, Nikolić, Hadžić, Terek, \& Nedeljković, 2012; Sue-Chan, Chen, \& Lam, 2011). These followers are more 
satisfied with the job, they achieve better performance, greater creativity and innovation, and are more committed to the organisation compared to followers from outside groups (Abu Elanain, 2014; Vukonjanski et al., 2012; O'Donnell, Yukl \& Taber, 2012; Lunenburg, 2010; Moss, Sanchez, Brumbaugh, \& Borkowski, 2009; Lee, 2008; van Breukelen, Schyns, \& Le Blanc, 2006; Mojić, 2002). Followers of the inner group rarely leave their jobs and have more performance appraisal (Green, 2008). Leaders and followers that have close relationships, usually help each other in career and personal life, often collaborating at work, but also informally outside of work. High quality exchange relations can be considered as social capital, which has a positive impact on organisational performance (Uhl-Bien, Graen, \& Scandura, 2000, according to Jiang et al., 2014; Moss et al., 2009). Followers from inner group are often exhausted because of the high business demands, even though they have more resources available than the followers from an external group (Jiang et al., 2014).

Members of the external group are mainly engaged in routine tasks (Stewart \& Johnson, 2009) and have more formal relations with superiors, which are characterized by low confidence, lack of attention, support, and less chances for prizes (Mumma 2010; Moss et al., 2009). Followers from the external group perform exclusively the work they were engaged in and which complies with the formal description of their work (Abu Elanin, 2014; Nikolić, Vukonjanski, \& Terek, 2012; Grean \& Uhl-Bein, 1995). They have less access to leader, fewer resources and limited access to information. The leader provides them with support, understanding and help, but only to the extent that it is their duty and professional obligation. These followers have fewer chances for advancement, may feel isolated and neglected, and they hardly develop a sense of attachment and commitment to the organisation (Loi, Mao, \& Ngo, 2009). Different treatment of followers is considered extremely unfair, which is why they often develop a sense of dissatisfaction, which is why they can become frustrated and motivated to leave their jobs.

Unlike the research that emphasize the one-dimensional character of the concept based on the behaviour of leaders and followers (Graen \& Uhl-Bien, 1995; Graen \& Scardura, 1987), some authors point to the multidimensional character of the relations of exchange between leaders and followers (Liden \& Maslyn; 1998; Liden, Sparrowe, \& Wayne, 1997; Dienesch \& Liden, 1986). Dimensions of exchange between leaders and followers are: loyalty, affect, contribution, professional respect (Liden \& Maslyn, 1998; Dienesch \& Liden, 1986). These dimensions behave like a currency conversion so that both sides have their own contribution in terms of exchange (Dienesch \& Liden, 1986, p. 625). Leaders expect currencies that are related to the performance of tasks, where relevant currency is contribution to job performance, while followers expect currencies that are related to the establishment of social relations, where 
relevant currencies are loyalty, affect and professional respect (Maslyn \& UhlBien, 2001). The exchange relations between leaders and followers can be based on one, two, three or all four dimensions (Liden et al., 1997).

Loyalty refers to the degree to which the leader and followers are loyal to each other. It represents the degree to which the leader and followers publicly support the activities and character of each other (Liden \& Maslyn, 1998, p. 46). Public support carries the risk and possible conflict, since followers and leaders who have not supported the opposite side lose the favor and trust of the other side. The commitment refers to the attachment between leaders and followers that occurs primarily on the basis of mutual attraction and not on the basis of work and professional values (Dienesch \& Liden, 1986, p. 625). It measures friendship and affection that leaders and followers feel towards each other and can occur in different forms, such as gestures of attention, care, support around personal problems, or informal socializing outside of work (Liden et al., 1997, p. 85). Contribution to the work relates to the perception of quality, care and attention that each member invests in the process of the achievement of common goals (Dienesch \& Liden, 1986, p. 624). This dimension is often explained as performing in a way that goes beyond the duties given in the job description (Maslyn \& Uhl-Bien, 2001, p. 699). Contribution to the conduct of the business also concerns the willingness of followers to work hard and devote extra effort to meet the goals of the leader (O'Donnell et al., 2012, p. 147), while the professional respect refers to the degree to which leaders and followers built a reputation for operational excellence inside and outside the organisation (Liden \& Maslyn, 1998, p. 50). Professionally respect can be communicated in different ways: through advice or expressing admiration for the skill and integrity of others (Liden et al., 1997, p. 87), and implies the respect of professional competence (Maslyn \& Uhl-Bien, 2001, p. 699).

The development of two-way relationship between the leader and follower takes place gradually, over a long period of time, so that the cycle of exchange is repeated continuously, until it reaches that point where it will exhibit a high degree of mutual dependence, loyalty and support, reflecting the increase the power that a leader has over the successor, and vice versa. This is, therefore, a process from which benefits not only the follower, but also the leader, since the commitment and support by group members plays an important role in the execution of duties and maintain leadership status. On the other hand, maintaining a special relationship with the preferred members of the group requires the leader to provide certain benefits in the exchange, in the form of attention, appreciation and understanding of the problems and needs of their followers. It is obvious that it is a reciprocal process that must be created gradually, through certain stages. 


\section{Path - goal Theory in LMX}

The path-goal theory essentially focuses on the motivation of employees in leader-follower relationship, and its main objective is to increase the performance and satisfaction of followers in the process of realisation of organisational goals (Northhouse, 2008, p. 87). Motivational function of the leader in this process is to increase the reward for the followers for the results achieved and to create the path to make it easier to obtain awards by explaining, removing barriers and increasing opportunities for the realisation of satisfaction performing a job (House, 1971, p. 324). The basis of this theory is in the understanding that the leaders will be effective to the extent to which they complement the environment in which their followers are working through the necessary clarifications of delegated tasks, in order to ensure that the followers can achieve organisational goals, to feel personal satisfaction and to receive adequate prize for accomplishing goals (House, 1996, p. 326). The focus is primarily on providing conditions for the success of a follower (Kamisu \& Wafa, 2014). The leaders will successfully motivate followers if they make business goals it desirable and if they help followers to understand the behaviours and strategies that lead to these desired outcomes (Knight, Shteynberg, \& Hanges, 2011).

Concrete leadership behaviour that will encourage the achievement of the goals depends on the characteristics of followers and the characteristics of the business environment (Indvik, 1986, p. 189). Characteristics of the business environment (structure of tasks, norms of business groups, degree of formalisation) determine the appropriate leadership behaviour that will help followers to achieve maximum results, while followers' characteristics (level of dependence, need for achievement, seeing their own abilities, etc.) determine how the business environment and leadership behaviour will be interpreted. In order to be effective, leaders apply behaviour that complements the business environment and abilities of followers, so it compensates for the shortcomings and helps followers to achieve job satisfaction and high individual and organisational performance (House, 1996, p. 324).

According to House (1971), there are four different leadership styles in the context of this theory: directive, participative, supportive and style focused on achievement. Each of these four styles can be applied in various combinations with different followers in different environments and situations (House \& Mitchell, 1974, according to Polston-Murdoch, 2013). The leader must be able to choose and adapt your leadership style to current and future conditions (Horses, 2014; Bucic, Robinson, \& Ramburuth, 2010). Leaders increase confidence in the success and satisfaction of followers by selecting the appropriate style. 
Directive style means letting followers know what is expected of them, scheduling and coordination of work, giving instructions and clarification of policies, rules and procedures (House, 1996, p. 326). This style allows for the elimination of ambiguity, linking effort of followers with the results achieved and the results achieved with benefits in the form of salaries, promotions, job security, etc. Directive style should be used when business tasks are relatively unstructured when followers have need for reducing uncertainties (Ratyan \& Mohd, 2013; Knight et al., 2011, Indvik, 1986). Preferably it is applied in interacting with new or inexperienced employees and situations that require immediate action (Polston-Murdoch, 2013).

Supporting style involves orientation towards satisfying the needs and preferences of followers, as well as expressing concern for the welfare of followers and creating a friendly and supportive environment (House, 1996, p. 326). This style is a source of self-esteem and personal satisfaction and it reduces stress and frustration (Horse, 2014, Knight, et al., 2011). It involves respecting followers, equal treatment of all employees and shows concern for the welfare of followers (Polston-Murdoch, 2013). The supporting style is suitable when followers have lack of faith in their own ability to perform tasks (Polston-Murdoch, 2013).

The participatory style involves encouraging followers to participate in decision-making, their opinions and suggestions about the way of doing business are taken into account (House, 1996, p. 327). This style of leadership has four major effects: linking efforts with the results and rewards, increasing compatibility of individual and organisational goals, increasing the autonomy of followers and the ability to realise their ideas, which leads to increasing the effort and consequently performance and increasing involvement and commitment of followers (House, 1996). This style has a large influence on the personality of followers and is more effective when followers prefer independence (Knight et al., 2011).

The style oriented towards achievement includes incentives for business excellence: setting challenging goals, striving for improvement, emphasizing high performance, indicating a belief that followers can achieve high standards of performance (House, 1996, p. 327). The leader encourages followers to strive for higher standards of performance and to have confidence in their ability to achieve challenging goals. The end result is increased performance and satisfaction of followers. This style is most effective when tasks are unstructured, ambitious, because in such situations, self-esteem of followers is low (Knight et al., 2011) and they need moral support to increase their belief that they can achieve the targets set (Polston-Murdoch, 2013). 


\section{Research Methodology}

Numerous studies show that the establishment of high-quality exchanges between leaders and followers has multiple positive effects on both the individual and organisational level (more job satisfaction, faster progress, greater commitment to the organisation, higher quality organisational performance, etc.). Also, it was shown that leaders use different styles in dealing with their followers. The subject of this work is to determine, from the perspective of a follower, the dependence of the quality of leader-member exchange and the perceived leadership style applied to interact with followers.

There are three main research objectives:

1. Demonstrating the quality of LMX in the studied organisations,

2. Demonstrate which leadership style followers perceived as the most commonly used by their leaders and

3. Showing whether the perception of followers about the quality of LMX affects the perception of the followers of the leadership style of their leaders.

The basic hypothesis is: perceived leadership style depends on the quality of the relationship between leaders and followers.

Derived hypotheses are: 1 . There is often higher quality of LMX in SOEs (state-owned enterprises), than in private companies; 2 . There is often higher quality of LMX in service organisations than in manufacturing companies; 3. Leaders have high-quality exchange relations with followers who are long-time employees of the company; 4 . The existence of high-quality LMX indicates a greater application of participatory and supportive style of leadership. 5. There's a difference between males and females in the perception of the connection between the quality of trade and leadership style.

The research is conducted in the period from July to October 2015, in the territory of the Republic of Serbia. Data were collected using survey research methods. The questionnaire, providing data consists of three parts. The first part of the questionnaire contains questions on gender, age, education level of respondents, the type of company they work for in terms of type of activity and type of ownership, and years of experience in a particular company.

The second part of the questionnaire relates to leadership styles. The original questionnaire (Indvik, 1988, according to Northouse, 2008) was used in order for leaders to assess their own leadership style, and for the purposes of this study, statements are adjusted so that the followers assess the leadership style of its leader. This part of the questionnaire consists of 20 statements grouped by 5 related to each style of leadership (directive, participative, 
supportive and style focused on achievements). Respondents expressed their level of agreement / disagreement with statements on a five-point Likert scale.

The third part of the questionnaire relates to measuring the quality of working relationships between leaders and followers. The questionnaire used for this purpose is the LMX-7 (Graen \& Uhl-Bien, 1995, p. 237), a questionnaire with seven items, which allows you to reliably measure the quality of the leader-follower exchange. This questionnaire is the most widely used questionnaires to measure the quality of LMX (Horse, 2014; Paglis \& Green 2002, according to Moss et al., 2009). Respondents expressed their level of agreement / disagreement with statements on a five-point Likert scale. The results are interpreted in accordance with the following guidelines: a very high quality of trade $=30-35$, high $=25-29$, medium $=20-24$, low $=15-19$, very low $=7-14$.

\section{Research variables are:}

- Leadership styles according to path-goal theory (directive, participative, supportive and style oriented towards achievements) and quality of leadermember exchange and

- The gender, age, educational structure, work experience of the respondents and the type of company.

Analysis was carried out on a sample of 12 companies, with a total of 100 respondents. The structure of respondents by gender, age and educational background is given in Table 1.

Table 1 Structure of the Sample

\begin{tabular}{|l|c|}
\hline \multicolumn{2}{|c|}{ Gender } \\
\hline Male Age \\
\hline Female & 55 \\
\hline \multicolumn{2}{|c|}{ Ag } \\
\hline$<25$ & 19 \\
\hline $26-35$ & 39 \\
\hline $36-45$ & 20 \\
\hline $46-65$ & 22 \\
\hline \multicolumn{2}{|c|}{ Education } \\
\hline Primary school & 2 \\
\hline High school & 54 \\
\hline College degree & 29 \\
\hline University degree & 4 \\
\hline MSc/Phd & 100 \\
\hline \multicolumn{2}{|c|}{ Total } \\
\hline
\end{tabular}

Source: Own research 
Descriptive analysis and one-way ANOVA are conducted, in order to determine whether there are statistically significant differences in terms of LMX in respondents with different work experiences, with different qualifications, different genders, who work in different types of companies. Also correlation analysis is performed in order to establish the link between the quality of LMX and the perceived leadership style. SPSS software is used for data analysis and presentation of results.

\section{The Research Results}

Based on the results, leadership style oriented towards achievements $66 \%$ is the most widely used leadership style is surveyed companies. In combination with it, participative style is used in $40 \%$ of enterprises. Directive leadership style is used as one of the styles, in $33 \%$ of the enterprises, but it is the dominant leadership style only in one enterprise. In $75 \%$ of companies, there are highquality relations of exchange between leaders and followers, while in $25 \%$ of companies there are medium quality exchange relations.

Looking from the perspective of a follower, $63 \%$ of respondents believe that their company has very high quality and high quality LMX. Taking into account the relations of medium quality, $80 \%$ of respondents believe that their company has the necessary exchange relations. Based on the results presented in Table 2, according to the followers, leadership style oriented towards the achievement is the most common style. After it, the most commonly used style is participatory, while supporting style is rarely applied.

Table 2 Leadership Style

\begin{tabular}{|c|c|c|c|c|}
\hline \multirow{2}{*}{ Leadership style } & \multicolumn{3}{|c|}{ Results interpretation } & \multirow{2}{*}{$\begin{array}{c}\text { Research results } \\
\text { Mean }\end{array}$} \\
\cline { 2 - 4 } & Usual result & Low result & High result & 28 \\
\hline Directive style & 23 & 18 & 28.6400 \\
\hline Supporting style & 28 & 23 & 33 & 18.8000 \\
\hline Participatory style & 21 & 16 & 26 & 18.8700 \\
\hline $\begin{array}{c}\text { Style oriented towards } \\
\text { achievements }\end{array}$ & 19 & 14 & 24 & 18.5300 \\
\hline
\end{tabular}

Source: Own research

According to the analysis, the quality of trade between leaders and followers decreases with increasing years of work experience in the company, as evidenced by the results presented in Table 3 . There are high-quality exchange relations (Mean> 25), with the followers who have up to 10 years of experience, 
while there are medium quality LMX with the employees with more than 10 years of experience.

Table 3 The Quality of LMX Depending on the Length of Work Experience

\begin{tabular}{|c|c|c|}
\hline Work experience & Number of followers & Mean (LMX7) \\
\hline Up to 1 year & 20 & 27.2000 \\
\hline 1-5 years & 27 & 25.9259 \\
\hline 5-10 years & 15 & 27.1333 \\
\hline$>10$ years & 38 & 24.1579 \\
\hline
\end{tabular}

Source: Own research

Table 4 The Quality of LMX Depending on the Company Type and Ownership Type

\begin{tabular}{|c|c|c|}
\hline Company type & Number of followers & Mean \\
\hline Manufacturing & 21 & 22.9048 \\
\hline Services & 79 & 26.4304 \\
\hline Ownership type & Number of followers & Mean \\
\hline SOE & 19 & 25.3684 \\
\hline Private enterprise & 81 & 25.7654 \\
\hline
\end{tabular}

Source: Own research

In order to perform analysis of variance and correlation analysis, the fulfillment of conditions for conducting these analyses is checked. Results Kolmogorov-Smirnov coefficient show that the assumption of normality of distribution for all variables is not fulfilled, but as $\mathrm{n}$ tends to infinity, the assumption that variables follow the normal distribution with increasing number of respondents, can be accepted, according to the central limit theorem. There is a linear relationship between the variables, so the assumption of homogeneity of variance is fulfilled, which is determined by observing the dispersion diagram.

One-way ANOVA is conducted in order to show whether there are statistically significant differences in the quality of exchange relations between leaders and followers in respondents with different work experiences, with different qualifications, different genders, who work in different types of businesses. The assumption of homogeneity of variance is tested first, by using Levin's test, and this assumption is not violated for any analyzes. 
There is a statistically significant difference at $\mathrm{p}<0.05$ in the quality of LMX between the manufacturing and service enterprises $(F(1,98)=0,5,164, \mathrm{p}$ $=0.025$ ). The magnitude of this difference is expressed by the use of eta squared is 0.05 , which according to Cohen's criterion indicates that the impact of differences in average. There was a statistically significant difference in the quality of LMX in the perception of the followers of different ages (there were four groups of patients: under 25 years, 26 - 35 years, 36 - 45 years and 46 - 65 years). There was a statistically significant difference at $\mathrm{p}<0.05$ in the results of the four age groups: $\mathrm{F}(3,96)=3.611, \mathrm{p}=0.016$. That impact, measured using the indicators eta squared, which amounts to 0.11 to Cohen's criterion indicates that the influence of big differences. Subsequent comparisons, done by Tukey's HSD test shows that, at the level of significance $\mathrm{p}<0.05$, the arithmetic mean of the group of followers under the age of 25 years (Mean $=28.2632, \mathrm{SD}=$ 5.8769) were significantly different from the mean age of the group of followers 45 years $($ Mean $=22.5909, \mathrm{SD}=6.28421)$.

On the other hand, it is found that there is no statistically significant difference in the quality of LMX between the state and private enterprises ( $F$ $(1,98)=0.058, p=0.811)$. It is shown that there is no statistically significant difference in the quality of LMX depending on the length of service $(F(3,96)=$ 1.357, $\mathrm{p}=2.61)$, nor depending on the qualifications of followers $(\mathrm{F}(4,95)=$ $0.335, \mathrm{p}=0.854)$, nor depending on the gender structure $(\mathrm{F}(1,98)=0.062, \mathrm{p}=$ 0.803).

The strength and direction of the correlation between the quality of LMX and perceived leadership styles are investigated by the Pearson linear correlation coefficient (Table 5). The analysis was conducted in two steps: first, the correlation between the high quality LMX and the perceived leadership style, and then the correlation between low quality LMX and the perceived leadership styles. The mean positive correlation was calculated between high quality LMX and directive style $(r=0.446, n=63, p<0.01)$, between the high quality LMX and supportive style $(\mathrm{r}=0.344, \mathrm{n}=63, \mathrm{p}<0.01$ ), a high-quality LMX and participative style $(\mathrm{r}=0.312, \mathrm{n}=63, \mathrm{p}<0.05)$ and a high-quality LMX and style oriented towards achievement $(\mathrm{r}=0.358, \mathrm{n}=63, \mathrm{p}<0.01)$. There is the highest positive correlation between high quality of LMX and directive style. However, if medium quality is taken into account, the results are significantly changed. The highest correlation exists between high-quality LMX and participative leadership style $(\mathrm{r}=0.486, \mathrm{n}=80, \mathrm{p}<0.01)$ and supportive style $(r=0.439, \mathrm{n}=80, \mathrm{p}<0.01)$. Correlations between low quality LMX and the perceived leadership styles are not statistically significant. 
376 Stojanović Aleksić, Stanisavljević, Bošković/Economic Themes, 54(3): 363-383

Table 5 Pearson Linear Correlation Coefficients (r) between High / Low-Quality LMX and the Perceived Leadership Styles

\begin{tabular}{|c|c|c|c|c|}
\hline $\begin{array}{l}\text { Leadership } \\
\text { style }\end{array}$ & & $\begin{array}{c}\text { High-quality LMX } \\
(\operatorname{lm} x \geq 25)\end{array}$ & $\begin{array}{c}\text { High-quality LMX } \\
(\operatorname{lm} x \geq 20)\end{array}$ & $\begin{array}{c}\text { Low-quality LMX } \\
(\operatorname{lm} x \leq 19)\end{array}$ \\
\hline \multirow{3}{*}{ Directive style } & $\begin{array}{l}\text { Pearson } \\
\text { correlation }\end{array}$ & $0,446^{* *}$ & $0,415^{* *}$ & 0,073 \\
\hline & Sig. (2-tailed) & 0,000 & 0,000 & 0,759 \\
\hline & $\mathrm{N}$ & 63 & 80 & 20 \\
\hline \multirow{3}{*}{ Supportive style } & $\begin{array}{c}\text { Pearson } \\
\text { correlation }\end{array}$ & $0,344^{* *}$ & $0,439 * *$ & 0,198 \\
\hline & Sig. (2-tailed) & 0,006 & 0,000 & 0,402 \\
\hline & $\mathrm{N}$ & 63 & 80 & 20 \\
\hline \multirow{3}{*}{$\begin{array}{l}\text { Participatory } \\
\text { style }\end{array}$} & $\begin{array}{c}\text { Pearson } \\
\text { correlation }\end{array}$ & $0,312^{*}$ & $0,486 * *$ & 0,057 \\
\hline & Sig. (2-tailed) & 0,013 & 0,000 & 0,812 \\
\hline & $\mathrm{N}$ & 63 & 80 & 20 \\
\hline \multirow{3}{*}{$\begin{array}{l}\text { Style oriented } \\
\text { towards } \\
\text { achievements }\end{array}$} & $\begin{array}{c}\text { Pearson } \\
\text { correlation } \\
\end{array}$ & $0,358^{* *}$ & $0,415^{* *}$ & 0,081 \\
\hline & Sig. (2-tailed) & 0,004 & 0,000 & 0,734 \\
\hline & $\mathrm{N}$ & 63 & 80 & 20 \\
\hline
\end{tabular}

Source: Own research

The coefficient of determination $r_{1}^{2}=0.1722$ indicates that a high-quality LMX explain $17.22 \%$ of the variance in perception of directive leadership style. The coefficient of determination $\mathrm{r}_{2}{ }^{2}=0.1927$ indicates that a high-quality exchange relations explain $19.27 \%$ of the variance in perception of supportive leadership style. The coefficient of determination $\mathrm{r}_{3}{ }^{2}=0.2362$ indicates that a high-quality exchange relations explain $23.62 \%$ of the variance in perception of participatory leadership style. The coefficient of determination $r_{4}{ }^{2}=0.1722$ indicates that a high-quality exchange relations explain $17.22 \%$ of the variance in perception of style aimed at the achievement. 
Stojanović Aleksić, Stanisavljević, Bošković/Economic Themes, 54(3): 363-383 377

Table 6 The correlation Coefficients for Gender Structure and Leadership Style

\begin{tabular}{|c|c|c|c|c|c|}
\hline Gender & & $\begin{array}{c}\text { Directive } \\
\text { style }\end{array}$ & $\begin{array}{c}\text { Supportive } \\
\text { style }\end{array}$ & $\begin{array}{c}\text { Participatory } \\
\text { style }\end{array}$ & $\begin{array}{c}\text { Style oriented } \\
\text { towards } \\
\text { achievements }\end{array}$ \\
\hline $\begin{array}{c}\text { Male } \\
(\mathrm{n}=35)\end{array}$ & $\begin{array}{c}\text { High-quality } \\
\text { LMX }\end{array}$ & 0,332 & $0,509^{* *}$ & $0,558^{* *}$ & $0,438^{* *}$ \\
\hline $\begin{array}{c}\text { Female } \\
(\mathrm{n}=45)\end{array}$ & $\begin{array}{c}\text { High-quality } \\
\text { LMX }\end{array}$ & $0,487^{* *}$ & $0,399^{* *}$ & $0,429^{* *}$ & $0,399^{* *}$ \\
\hline \multicolumn{7}{|c|}{$-0,82251$} & 0,592378 & 0,737276 & 0,204562 \\
\hline \multicolumn{2}{|c|}{$\mathrm{Z}_{\text {ops }}$} & -0.01 level (2-tailed). \\
\hline
\end{tabular}

Source: Own research

A strong positive correlation was observed in terms of male followers between the high-quality LMX and participative leadership style $(\mathrm{r}=0.558, \mathrm{n}=$ $35, \mathrm{p}<0.01)$, and between the high-quality LMX and supportive style $(\mathrm{r}=$ $0.509, \mathrm{n}=35, \mathrm{p}<0.01$ ). For men, the mean positive correlation exists between high quality LMX and style oriented towards achievement $(r=0.438, n=35, p$ $<0.01$ ), while the correlation between the high quality LMX and directive style is not statistically significant. For female followers, medium positive correlation exists between high-quality LMX and all leadership styles, but it is the strongest among high-quality LMX and directive style $(r=0.487, \mathrm{n}=45, \mathrm{p}<0.01)$. The correlation between the high-quality LMX and directive style for men is not significant, while for women there is medium correlation, but the difference between these coefficients is not statistically significant $\left(\mathrm{r}_{1 \mathrm{M}}=0.332, \mathrm{r}_{1 \mathrm{Z}}=\right.$ $0.487, \mathrm{z}_{1}=-0.82251$ ). The correlation between the high-quality LMX and supportive style for men is strong, while it is medium for women, but there is no statistically significant difference in these coefficients $\left(\mathrm{r}_{2 \mathrm{M}}=0.509, \mathrm{r}_{2 \check{z}}=0.399\right.$, $\mathrm{z}_{2}=0.592378$ ). The correlation between the high-quality LMX and participative style for men is strong, while it is medium for women, but there is no statistically significant difference between these coefficients $\left(\mathrm{r}_{3 \mathrm{~m}}=0.558, \mathrm{r}_{3 \check{z}}=\right.$ $0.429, \mathrm{z}_{3}=0.737276$ ). A positive correlation exists between high-quality LMX and style oriented towards achievements for both men and women, but there was no statistically significant difference in the correlation coefficients $\left(\mathrm{r}_{4 \mathrm{M}}=\right.$ $\left.0.438, \mathrm{r}_{4 \check{z}}=0.399, \mathrm{z}_{4}=0.204562\right)$. These results are shown in Table 6 .

\section{Discussion and Conclusion}

Since followers of the inner group have higher productivity, motivation, dedication and achieve higher performance, it is suggested that leaders develop high-quality exchange relations with as many followers as possible. It is necessary to establish the largest possible inner group and the smallest possible external group (Lunenburg, 2010). According to various theories, it is believed that the employee will achieve better results when there is a good and healthy 
relationship between leaders and followers, and when all the leaders relate to all the followers in the same way (Islam et al., 2013, p. 80). Leaders should be aware of what their followers expect from them in order to be able to adapt their behavior, leadership style, and to give followers an offer they cannot refuse (Schyns et al., 2008). Different styles of leadership should be applied in different situations depending on the characteristics of followers and environmental characteristics. However, the subject of analysis in this paper are not the characteristics of followers and environmental characteristics that determine leadership style, but the quality of exchange relations between leaders and followers (LMX - leader-member exchange) from the perspective of followers and their perception of leadership styles applied by their leaders.

The results show that the style oriented towards achievements is the most commonly perceived leadership style in $66 \%$ of surveyed companies. Since leaders use different styles in their dealings with different followers and in different situations, it is observed that after the achievement-oriented style, participative style is commonly applied, directive style is rarely applied, while supportive style is very rare. There are high quality exchange relations between leaders and followers in $75 \%$ of companies. In addition, $63 \%$ of respondents believe that there are very high-quality and high-quality exchange relations in their company. If we take into account the exchange relations of medium quality, then $80 \%$ of respondents believe that their company has the necessary LMX.

One-way ANOVA shows that there are no statistically significant differences in the quality of exchange between the leader and followers at different dimensions. Thus, the quality of LMX decreases with the increase of years of work experience in the company, but the difference in the quality of exchange relations is not statistically significant. There was no statistically significant difference in the quality of LMX neither depending on the qualifications of followers, nor by gender. A statistically significant difference in the quality of LMX exists in the perception of followers who are of different ages, between a group of followers under the age of 25 years and a group of followers over the age of 45 years. The followers from service organisations estimate that there are exchange relations of high quality, while respondents from manufacturing companies estimate LMX as medium quality, and the oneway ANOVA shows that this difference is statistically significant. In both state and private enterprises there are high-quality relations of exchange between leader and followers, so there is no statistically significant difference in the quality of LMX between the state and private companies.

Correlation analysis revealed a link between the high-quality LMX and leadership styles. The biggest positive (mean) correlation was found between the high-quality LMX and directive style. However, when medium quality LMX is included in the analysis, the results change. The highest correlation 
exists between the high and medium quality of LMX and participative leadership style. Men perceived greater use of participatory leadership style when there are high-quality LMX (strong positive correlation). A strong positive correlation exists between high quality LMX and supportive style, which again points to the importance that men give this leadership style in building high-quality relations of exchange. For women, there is a correlation between all leadership styles and high-quality LMX. However, the correlation is the strongest for the directive and participative style. Despite these differences, further analysis shows that there are no statistically significant difference between men and women in correlation coefficients that measure the correlation of high-quality leader-member exchange relations and the perceived leadership styles.

Results of research also show that the largest (although medium) positive correlation exists between high-quality LMX and participatory, and after that the supportive leadership style. In the opinion of the investigated followers, in $66 \%$ of enterprises style oriented towards achievements is the most commonly used leadership style, even though the results show that there are high-quality LMX in $75 \%$ of enterprises. These results indicate that the quality of the exchange between leaders and followers could improve with the application of participatory and supportive leadership style. The leader cannot apply the same style in every situation, and advice for improving relations with followers is the application of various styles. How participatory and supportive styles lead to improvements in the terms of exchange relations, it is recommended that leaders use them more often.

Work has certain limitations, which also represent the suggestions for future research. Specifically, quality of exchange relations between leader and follower was measured by using LMX-7, which is a one-dimensional instrument. In addition to this questionnaire, it is possible to use questionnaire LMX-MDM to explore the same relation (Liden \& Maslyn, 1998). This instrument has greater coverage and reflects the views of the followers better (Wang, Law, Hackett, Wang, \& Chen, 2005, according to Ansari et al., 2007). The multidimensional concept of leader-follower exchange relations can provide a better theoretical basis and greater accuracy in empirical research (Dienesch \& Liden, 1986). As in any research carried out by using questionnaires, remains the question of respondents' sincerity and real commitment when completing the questionnaire. More reliable results can be obtained by increasing the sample of respondents and the introduction of new variables that affect the perception of followers on the quality of LMX and applied styles of leadership by their leaders. Future research should be directed precisely to the inclusion of a large number of variables that could influence the choice of leadership style, as well as greater coverage in terms of number of participating companies and the number of respondents. 
380 Stojanović Aleksić, Stanisavljević, Bošković/Economic Themes, 54(3): 363-383

\section{References}

Abu Elanain, H.M. (2014). Leader-member exchange and intent to turnover. Management Research Review, 37(2), 110-129.

Ansari, M.A., Mui Hung, D.K., \& Aafaqi, R. (2007). Leader-member exchange and attitudinal outcomes: role of procedural justice climate. Leadership \& Organization Development Journal, 28(8), 690-709.

Bucic, T., Robinson, L., \& Ramburuth, P. (2010). Effects of leadership style on team learning. Journal of Workplace Learning, 22(4), 228-248.

Casimir, G. \& Keith Ng, Y.N. (2010). Combinative aspects of leadership style and the interaction between leadership behaviors. Leadership \& Organization Development Journal, 31(6), 501-517.

Cookson, R.L. (2011). The Moderating Effect of Leader Prototypicality on the Relationship between LMX and Follower Attitudes, Master thesis (https://smartech.gatech.edu/bitstream/handle/1853/42709/cookson rober t_l_201108_mast.pdf Accessed 12 July 2015).

Dienesch, R.M. \& Liden, R.C. (1986). Leader-Member Exchange Model of Leadership: A Critique and Further Development. Academy of Management Review, 11(3), 618-634.

Gómez, C. \& Rosen, B. (2001). The Leader-Member Exchange as a Link between Managerial Trust and Employee Empowerment. Group \& Organization Management, 26(1), 53-69.

Graen, G.B. \& Scadura, T.A. (1987). Toward a Psyhology of Dyadic Organizing. Research in Organizational Behavior, 9, 175-208.

Graen, G.B. \& Uhl-Bien, M. (1995). Relationship-Based Approach to Leadership: Development of Leader-Member Exchange (LMX) Theory of Leadership over 25 Years: Applying a Multi-Level Multi-Domain Perspective. Leadership Quarterly, 6(2), 219-247.

Green, C. (2008). Leader member exchange and the use of moderating conflict management styles: Impact on relationship quality. International Journal of Conflict Management, 19(2), 92-111.

House, R.J. (1971). A Path Goal Theory of Leader Effectiveness. Administrative Science Quarterly, 16(3), 321-339.

House, R.J. (1996). Path goal theory of leadership lessons legacy and a reformulated theory. Leadership Quarterly, 7(3), 323-352.

Indvik, J. (1986). Path-Goal Theory of Leadership: A Meta-Analysis. Academy of Management Best Papers Proceedings, 189-192.

Islam, T., ur Rehman, S., \& Ahmed, I. (2013). Investigating the mediating role of organisational politics between leadership style and followers' behavioral outcomes. Business Strategy Series, 14(2/3), 80-96.

Jiang, J.Y., Law, K.S., \& Sun J.J.M. (2014). Leader-Member Relationship and Burnout: The Moderating Role of Leader Integrity. Management and Organization Review, 10(2), 223-247. 
Kamisah, D.A.B. \& Wafa S.A. (2014). The Leadership Style Preference among Sabah Ethnicities. International Journal of Human Resource Studies, 4(1), 259-265.

Knight, A.P., Shteynberg, G., \& Hanges, P.J. (2004). Path-goal analysis. In J.M. Burns, G. R. Goethals, \& G. J. Sorenson (Eds.), Encyclopedia of leadership (pp.1164-1169). Massachusetts: Sage Publications.

Konja, V. (2014). Uticaj komunikacije lidera i saradnika na organizacionu posvećenost zaposlenih. doktorska disertacija (http://www.cris.uns.ac.rs/DownloadFileServlet/Disertacija13981575429 8447.pdf?controlNumber=\%28BISIS\%2986216\&fileName $=1398157542$ 98447.pdf\&id=1830 Accessed at 17 July 2015).

Lee, J. (2008). Effects of leadership and leader-member exchange on innovativeness. Journal of Managerial Psychology, 23(6), 670-687.

Liden, R.C. \& Graen, G. (1980). Generalizability of the Vertical Dyad Linkage Model of Leadership. Academy of Management Journal, 23(3), 451-465.

Liden, R.C., Sparrowe, R.T. \& Wayne, S.J. (1997). Leader-member exchange theory: the past and potential for the future. Research in Personnel and Human Resources Management, 15, 47-119.

Liden, R.C. \&. Maslyn, J.M (1998). Multidimensionality of Leader-Member Exchange: An Empirical Assessment through Scale Development. Journal of Management, 24(1), 43-72.

Loi, R., Mao, Y. \& Ngo, H. (2009). Linking Leader-Member Exchange and Employee Work Outcomes: The Mediating Role of Organizational Social and Economic Exchange. Management and Organization Review, 5(3), 401-422.

Lunenburg, F.C. (2010). Leader-Member Exchange Theory: Another Perspective on the Leadership Process. International Journal Of Management, Business, And Administration, 13(1), 1-5.

Maslyn, J.M. \& Uhl-Bien, M. (2001). Leader-Member Exchange and Its Dimension: Effects of Self-Effort and Other's Effort on Relationship Quality. Journal of Applied Psychology, 86(4), 697-708.

Mumma, S. (2010). Student Leader LMX Relationships as Moderated by Constructive-Developmental Theory. Theses, Dissertations, \& Student Scholarship: Agricultural Leadership, Education \& Communication Department, Paper 9 (http://digitalcommons.unl.edu/aglecdiss/9 Accessed at 12 July 2015).

Mojić, D. (2002). Noviji pristupi izucavanju vodjstva u organizacijama. Sociologija, 44(2), 139-160.

Moss, S.E., Sanchez, J.I., Brumbaugh, A.M., \& Borkowski, N. (2009). The Mediating Role of Feedback Avoidance Behavior in the LMXPerformance Relationship. Group \& Organization Management, 34(6), 645-664. 
Nikolić, M., Vukonjanski, J., \& Terek, E. (2012). Stanje liderstva i LMX u preduzecima u Srbiji. Tehnika - Menadžment, 67(2), 287-292.

Northouse, P.G. (2008). Liderstvo: teorija i praksa, Beograd: Data Status.

O'Donnell, M., Yukl, G., \& Taber, T. (2012). Leader behavior and LMX: a constructive replication. Journal of Managerial Psychology, 27(2): 143154.

Polston-Murdoch, L. (2013). An Investigation of Path - Goal Theory, Relationship of Leadership Style, Supervisor - Related Commitment and Gender. Emerging Leadership Journeys, 6(1), 13-44.

Ratyan, A.T. \& Mohd, R.A. (2013). Overview of Path-Goal leadership Theory. Comprehensive Research Journal of Education and General Studies, 1(1), 001-005.

Schyns, B., Kroon, B., \& Moors, G. (2008). Follower characteristics and the perception of leader member exchange. Journal of Managerial Psychology, 23(7), 772-788.

Stewart, M.M. \& O.E. Johnson (2009). Leader-Member Exchange as a Moderator of the Relationship Between Work Group Diversity and Team Performance. Group \& Organization Management, 34(5), 507-535.

Sue-Chan, C., Chen, Z., \& Lam, W. (2011). LMX, Coaching Attributions, and Employee Performance. Group \& Organization Management, 36(4), 466498.

Van Breukelen, W., Schyns, B., \& Le Blanc, P. (2006). Leader-Member Exchange Theory and Research: Accomplishments and Future Challenges. Leadership, 2(3), 295-316.

Vukonjanski, J., Nikolić, M., Hadžić, O., Terek, E., \& Nedeljković, M. (2012). The relationship between globe organisational culture dimensions, job satisfaction and leader member exchange in Serbian organisations. Journal for East European Management Studies, 17(3), 333-368.

\section{ZAVISNOST ODNOSA RAZMENE LIDER - SLEDBENIK I LIDERSKOG STILA: ISTRAŽIVANJE U SRPSKIM ORGANIZACIJAMA}

Apstrakt: Međuzavisnost ponašanja lidera, liderskih stilova i interpersnalnih relacija sa sledbenicima ukazuje na neophodnost istraživanja različitih aspekata liderstva iz ugla sledbenika, što predstavlja osnovni predmet istraživanja u radu. Studija ima za cilj da utvrdi kvalitet odnosa razmene lider-član (engl. leader-member exchange), kako bi se došlo do zaključka o tome da li percepcija sledbenika o kvalitetu odnosa razmene utiče na stil liderstva i koji stil se najčešće koristi. Empirijska studija je sprovedena 2015. godine u Republici Srbiji, na uzorku od 100 ispitanika, zaposlenih u 12 organizacija, metodom ankete. Rezultati su pokazali da je najveća pozitivna korelacija između visokog kvaliteta odnosa razmene lider- 
član i participativnog liderskog stila. Po mišljenju sledbenika, stil orijentisan na postignuća je najčešći, bez obzira na činjenicu da postoje visoko kvalitetni odnosi razmene lider-član u većini preduzeća u uzorku. Značaj istraživanja ogleda se u osvetljavanju uloge sledbenika u procesu organizacionog liderstva, kao aktivnih i ravnopravnih učesnika. Praktičan dopinos ogleda se u davanju smernica liderima za aktivnije uključivanje sledbenika u proces donšenja odluka i prilagodjavanje liderskog stila specifičnostima samih sledbenika, kao i zahtevima situacionih okolnosti. Istraživanja ovog tipa nisu dovoljno prisutna $u$ domaćoj organizacionoj teoriji i praksi.

Ključne reči: odnosi razmene lider-sledbenik, dvosmerni pristup liderstvu, stilovi liderstva, interpersonalne relacije, sledbenici

\section{Authors' biographies}

Vesna Stojanović Aleksić is an Associate Professor at the Faculty of Economics, University of Kragujevac. She holds a PhD from the Faculty of Economics in Kragujevac, in the field of management and organisation. She teaches the following subjects: Organisation of Enterprise, Organisational Behavior and Leadership, at the same university. She has published a monograph and dozens of scientific papers in journals and conference proceedings of international and national importance. She has participated in numerous conferences, seminars and workshops at home and abroad. She is engaged in the projects of the Ministry of Education, Science and Technological Development of the Republic of Serbia. She has been the advisor on several Master's theses and doctoral dissertations.

Milena Stanisavljević is a teaching assistant at the Faculty of Technical Sciences, University of Kragujevac, on the following subjects: Foundations of Economics, Financial Management and Change Management. She has completed undergraduate and master academic studies at the Faculty of Economics in Kragujevac and currently is a $\mathrm{PhD}$ student at the same university. Her areas of scientific interest are organisation, organisational changes and entrepreneurial economy.

Aleksandra Bošković is a teaching assistant at the Faculty of Economics, University of Kragujevac, on the subject Organisation of Enterprise. She has completed undergraduate and master academic studies at the Faculty of Economics in Kragujevac and currently is a $\mathrm{PhD}$ student at the same university. Her areas of scientific interest are organisation, management, organisational changes and social responsibility of an organisation. 